\title{
The Trace Input of Cyanide to Jiaozhou Bay
}

\section{Dongfang Yang ${ }^{1,2,3, a}$, Sixi Zhu ${ }^{1,2}$, Mingzhong Long ${ }^{1,2}$, Danfeng Yang ${ }^{1,2}$, and Fengyou Wang}

${ }^{1}$ Research Center for Karst Wetland Ecology, Guizhou Minzu University, Guiyang 550025, China;

${ }^{2}$ College of Chemistry and Environmental Science, Guizhou Minzu University, Guiyang 550025, China;

${ }^{3}$ College of Information Science and Engineering, Fudan University, Shanghai, 200433, China

${ }^{4}$ North China Sea Environmental Monitoring Center, SOA, Qingdao 266033, China.

adfyang_dfyang@126.com; bcorresponding author; 'fywang@yahoo.com.cn.

Key words: Cyanide; Content; Distribution; Input strength; Jiaozhou Bay.

Abstract. This paper analyzed the content, pollution level, pollution source and input of cyanide in Jiaozhou Bay 1983. Results showed that cyanide contents in surface waters were 0.02-0.46 $\mu \mathrm{g} \mathrm{L}^{-1}$, which were much lower than the guide line of cyanide in Grade I $\left(5.00 \mu \mathrm{g} \mathrm{L}^{-1}\right)$ of National Sea Water Quality Standard (GB 3097-1997), indicating that this bay was very slight polluted by cyanide in 1983. In according to the spatial distribution of cyanide, we found that river flow and marine terminals were the major sources, whose input strengths were $0.14-0.46 \mu \mathrm{g} \mathrm{L}^{-1}$ and $0.42 \mu \mathrm{g}$ $\mathrm{L}^{-1}$, respectively. Cyanide in Jiaozhou Bay was mainly generated by human activities, and source-management was essential to environmental controls in Jiaozhou Bay.

\section{Introduction}

The cyanide-containing waste water has been increasing along with the rapid development of industries, yet the waste water treatment was always lagging. Hence, cyanide pollution has been serious environmental problems in many countries and regions due to the high toxicity of cyanide. The ocean is the sink of various pollutants, and the cyanide pollution in the marine environmental would finally cause harm to human beings [1-2]. Hence, understanding the content, pollution level, pollution source and input strength of cyanide in marine bay is meaningful to marine environment protection.

Jiaozhou Bay is located in south of Shandong Peninsula eastern China, and arrounded by economic developed cities of Qingdao, Jiaozhou and Jiaonan which are the "frontier" of Chinese Reform and Opening. With the increasing of waste water discharge, this bay has been sufferring from various pollutants including cyanide [1-2]. Based on the investigation data on cyanide in surface waters in Jiaozhou Bay in 1983, the aim of this paper was to analysis the content, pollution level, pollution source and input strength of cyanide, and to provide basis to marine environment protection. 


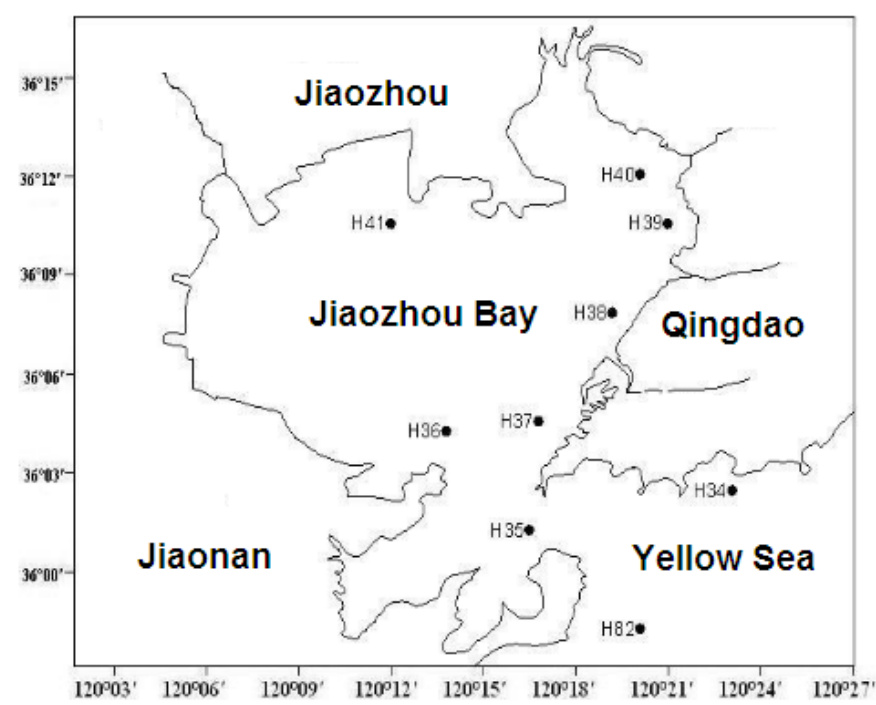

Fig.1 Geographic location and monitoring sites in Jiaozhou Bay

\section{Material and method}

Jiaozhou Bay $\left(35^{\circ} 55^{\prime}-36^{\circ} 18^{\prime} \mathrm{N}, 120^{\circ} 04^{\prime}-120^{\circ} 23^{\prime} \mathrm{E}\right)$ is located in the south of Shandong Peninsula, eastern China (Fig. 1). The total area, average water depth and bay mouth width are $446 \mathrm{~km}^{2}, 7 \mathrm{~m}$ and $3 \mathrm{~km}$, respectively. This semi-closed bay has more than ten inflow rivers such as Haibo Rriver, Licun Rriver, Baisha Rriver, and Loushan Rriver etc., most of which have seasonal features[3-4], and have been input channels of various pollutants to the bay [1-2].

The data for this paper was provided by North China Sea Environmental Monitoring Center. The survey was conducted in May, September and October 1983 (Fig. 1). Cyanide in surface waters was collected and measured followed by National Specification for Marine Monitoring [5].

\section{Results and discussion}

Content and pollution level of cyanide. The contents of cyanide in surface waters in May, September and October were 0.03-0.14 $\mu \mathrm{g} . \mathrm{L}^{-1}, 0.02-0.42 \mu \mathrm{g} . \mathrm{L}^{-1}$ and $0.13-0.46 \mu \mathrm{g} . \mathrm{L}^{-1}$, respectively (Fig. 1). In according to the guide line of cyanide in Grade I $\left(5.00 \mu \mathrm{g} \mathrm{L}^{-1}\right)$ of National Sea Water Quality Standard (GB 3097-1997), the contents of cyanide in 1983 were still very low, and this bay was very slightly polluted by cyanide in the early stage of Reform and Opening.

Distributions of cyanide. In May, high value of cyanide contents $\left(0.14 \mu \mathrm{g} . \mathrm{L}^{-1}\right)$ was occurring in Site H38 located in the estuaries of Licun River and Haibo River, and the high value region was formed in the coastal area in the northeast of the bay, and the cyanide contents were decreasing from the high value center to the south of the bay $\left(0.03 \mu \mathrm{g} \mathrm{L}^{-1}\right)$ (Fig. 2). In September, high value of cyanide contents $\left(0.42 \mu \mathrm{g} \mathrm{L}^{-1}\right)$ was occurring in Site $\mathrm{H} 37$ located in the coastal area in the east of the bay, and the cyanide contents were decreasing from the high value center to the bay mouth $(0.17$ $\left.\mu \mathrm{g} \mathrm{L}^{-1}\right)$ and then the out side of the bay mouth $\left(0.02 \mu \mathrm{g} \mathrm{L}^{-1}\right)$ (Fig. 3). In October, high value of cyanide contents $\left(0.46 \mu \mathrm{g} \mathrm{L}^{-1}\right)$ was occurring in Site H38 located in the estuaries of Licun River and Haibo River, and the cyanide contents were decreasing from the high value center to the bay mouth $\left(0.17 \mu \mathrm{g} \mathrm{L}^{-1}\right)$ and then the out side of the bay mouth $\left(0.14 \mu \mathrm{g} \mathrm{L}^{-1}\right)$ (Fig. 4). 


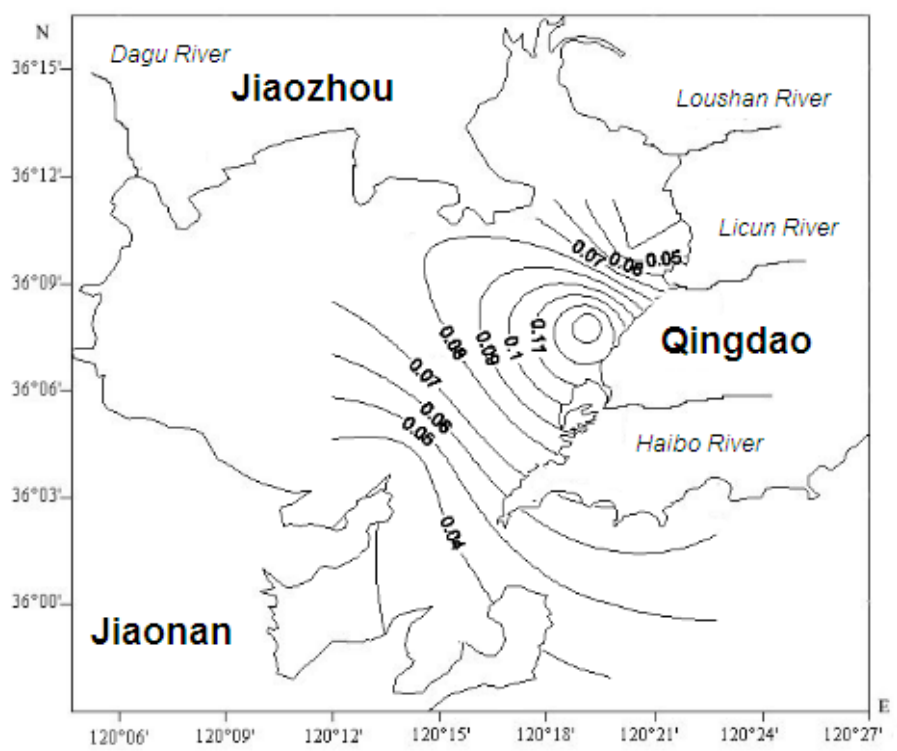

Fig. 2 Spatial distribution of cyanide in surface waters in Jiaozhou Bay in May 1983/ $\mu \mathrm{g} \mathrm{L}^{-1}$

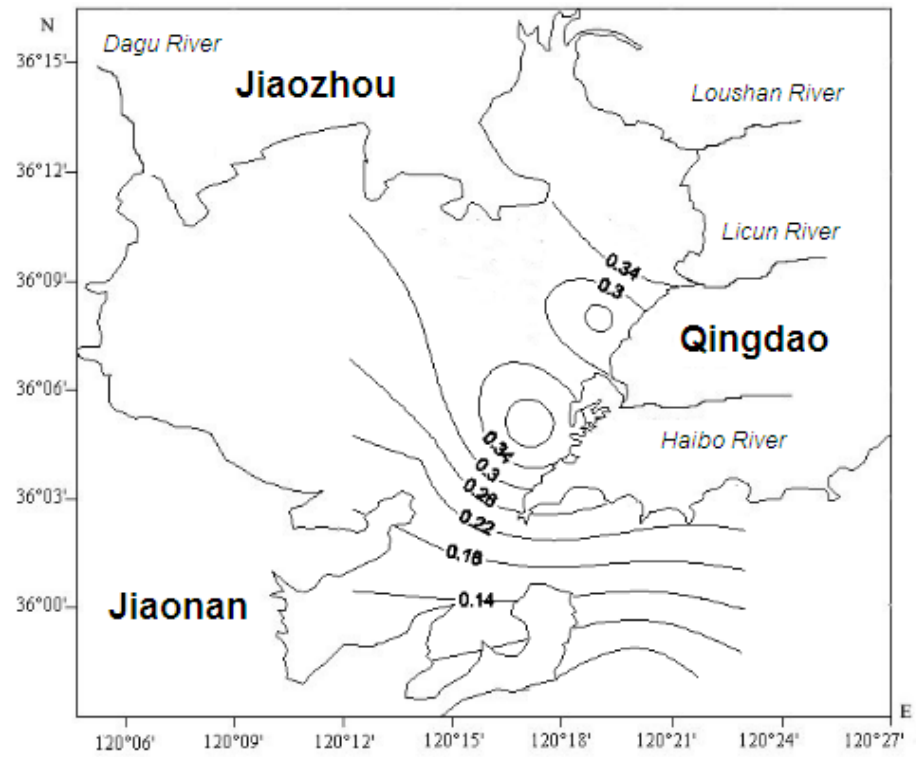

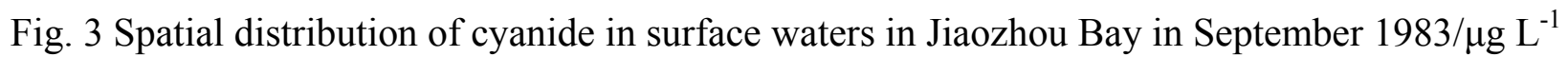




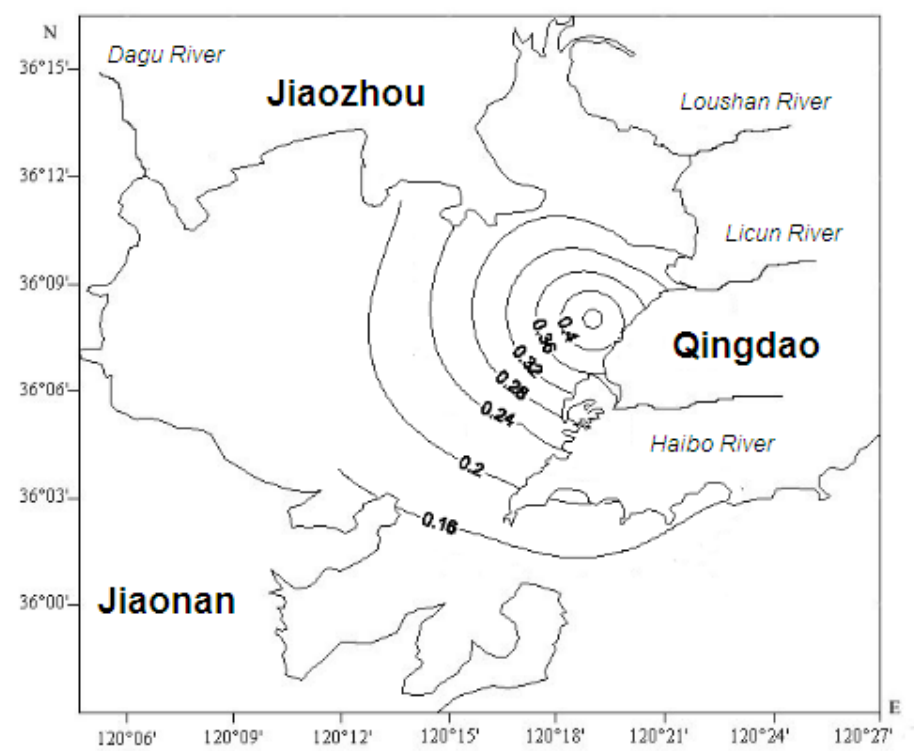

Fig. 4 Spatial distribution of cyanide in surface waters in Jiaozhou Bay in October $1983 / \mu \mathrm{g} \mathrm{L}-1$

Input of cyanide. The pollution sources of cyanide could be identified by the spatial distributions of the contents of cyanide. High value regions of cyanide contents were occurring in the estuaries of Licun River and Haibo River in May and October, indicated that river flow was one of the major sources of cyanide. High value regions of cyanide contents were occurring in the coastal area in the east of the bay, indicated that marine terminal was one of the major sources of cyanide. In according to the contents and distributions of cyanide, it could be concluded that the major sources of cyanide were river flow and marine terminal, whose input strengths were $0.14-0.46 \mu \mathrm{g} \mathrm{L}^{-1}$ and $0.42 \mu \mathrm{g} \mathrm{L}^{-1}$, respectively. Cyanide in Jiaozhou Bay was mainly generated by human activities, and source-management was essential to environmental controls in Jiaozhou Bay.

\section{Conclusion}

The contents of cyanide in surface waters in Jiaozhou Bay was $0.02-0.46 \mu \mathrm{g} . \mathrm{L}^{-1}$ in 1983 , and this bay was very slightly polluted by cyanide in the early stage of Reform and Opening. The major sources of cyanide were river flow and marine terminal, whose input strengths were 0.14-0.46 $\mu \mathrm{g}$ $\mathrm{L}^{-1}$ and $0.42 \mu \mathrm{g} \mathrm{L}^{-1}$, respectively. Cyanide in Jiaozhou Bay was mainly generated by human activities, and source-management was essential to environmental controls in Jiaozhou Bay.

\section{Acknowledgement}

This research was sponsored by Doctoral Degree Construction Library of Guizhou Nationalities University, Education Ministry's New Century Excellent Talents Supporting Plan (NCET-12-0659), the China National Natural Science Foundation (31560107) , Major Project of Science and Technology of Guizhou Provincial ([2004]6007-01), Guizhou R\&D Program for Social Development (Qiankehe SZ zi [2014] 3036) and Research Projects of Guizhou Nationalities University ([2014]02), Research Projects of Guizhou Province Ministry of Education (KY [2014] 266), Research Projects of Guizhou Province Ministry of Science and Technology (LH [2014] 7376).

\section{References}

[1] Yang DF, He XH, Gao J, et al.: Materials, Environmental and Biological Engineering. Vol. (2015), p. 40-43. 
[2] Yang DF, He XG, Gao J, et al.: Advanced Materials Research, Vol.1092-1093 (2015), p. 992-995.

[3] Yang DF, Chen Y, Gao ZH, et al.:Chinese Journal of Oceanology Limnology, Vol. 23(2005), p. 72-90.

[4] Yang DF, Wang F, Gao ZH, et al.: Maine Science, Vol. 28(2004): 71-74. (in Chinese with English abstract)

[5] State Ocean Administration. The specification for marine monitoring: Beijing, Ocean Precess, (1991). 